Manuela Ingaldi ${ }^{1}$, Marek Krynke ${ }^{2}$

\title{
MISJA W ZARZĄDZANIU PRZEDSIĘBIORSTWEM
}

\begin{abstract}
Streszczenie: Celem artykułu jest przedstawienie funkcji i roli misji w zarządzaniu przedsiębiorstwem. Na początku autorzy podjęli się próby zdefiniowania misji przedsiębiorstwa. Następnie opisali różne funkcje i formy misji. Przedstawiono także, jak misja przedsiębiorstwa powinna być projektowana i realizowana. Podano także przykłady misji w różnych branżach.
\end{abstract}

Slowa kluczowe: zarządzanie, misja przedsiębiorstwa, funkcje misji

\section{Definicja misji przedsiębiorstwa}

Misja przedsiębiorstwa jest ważnym elementem w zarządzaniu przedsiębiorstwem. Istnieje wiele definicji misji. Wiele z nich jest bardzo skomplikowanych, złożonych, co sprawia, że misja jest czymś górnolotnym, elementem oderwanym od rzeczywistości, od realiów działania przedsiębiorstwo. Jednak misja w rzeczywistości można zdefiniować w prosty sposób.

Wg Wawrzyniaka (WAWRZYNIAK B. 1989) misja przedsiębiorstwa to jego przedmiot aspiracji, czyli trwałych dążeń wyznaczających zakres społecznej działalności przedsiębiorstwa.

Podobną definicję przedstawili Stoner i Wankel oraz Stochowski. Dla Stonera i Wankela (StONER J.A.F., WANKel C. 1992) Misja to szczególny powód istnienia organizacji wyróżniający się od wszystkich innych. Natomiast dla Stachowskiego (STACHOWSKI W. 1994) Misja, to inaczej wspólne wartości przyjmowane przez wszystkich pracowników i zarząd firmy.

1 Dr inż., Politechnika Częstochowska, Wydział Zarządzania, Instytut Inżynierii Produkcji, e-mail: manuela@gazeta.pl

${ }^{2} \mathrm{Dr}$ inż., Politechnika Częstochowska, Wydział Zarządzania, Instytut Inżynierii Produkcji, e-mail: krynke@zim.pcz.pl 
Wg Sudoła misja przedsiębiorstwa jest to zestaw wartości akcentujący specyficzną rolę danej organizacji na rzecz otoczenia, tym samym uzasadniających istnienie danej jednostki (SUDOŁ S. 1999).

Szersze pojęcie misji zostało przedstawione przez Dwojnickiego oraz Pierścionka. Dwojniki (DwOJNICKI P. 1995) napisał, że misja jest generalnym uzasadnieniem racji istnienia i rozwoju organizacji. Określa główne wartości dla których organizacja została powołana, bądź które realizuje przez swoją działalność. Ważną funkcję przypisywaną misji jest ukierunkowywanie przyszłego działania. Natomiast Pierścionek (PIERŚCIONEK Z. 1996) twierdzi, że misja określa rolę jaką spełnia przedsiębiorstwo na rzecz otoczenia. Rolę nadzwyczajną, tzn. misja określa, co nadzwyczajnego, czego nie dają inne firmy, dostarcza moja firma. Te nadzwyczajne wartości wiążą się ze źródłami przewagi konkurencyjnej

Misja określa sens istnienia firmy, jej główne i najważniejsze zadanie oraz wartości oferowane klientom/konsumentom. Odpowiada na pytania "Po co istnieje przedsiębiorstwo?”, "Jakie zaspokaja potrzeby?”, „Jakie wartości dodane daje klientom?" (KISIL A., DUDZIAK W. 2012), (http://www.investopedia.com).

Misja jest ukonkretnieniem pomysłu na przedsiębiorstwo. Misja tworzy osobowość organizacji. Powinna odpowiadać na pytania po co istnieje przedsiębiorstwo, do czego dąży, określenie zbioru klientów, jakie zaspokaja potrzeby (KoŹMIŃSKI A. K. 1998), (RADTKE J. M. 1998).

Misję przedsiębiorstwa można więc traktować jako deklarację celów działalności tego przedsiębiorstwa. Powinna zawierać plany bieżących i przyszłych działań przedsiębiorstwa związanych z klientem czy produktem oraz przedstawiać pewne systemy wartości. Odpowiednio zaprojektowana misja pozwala odróżnić dane przedsiębiorstwo od podobnych, działających na rynku. Pomaga określać strategiczne cele przedsiębiorstwa (HILl CH., JONES G. 2008).

Dobrze określona misja przedsiębiorstwa spełnia kilka podstawowych funkcji (KISIL A., DUDZIAK W. 2012): 
- Stanowi doskonałe narzędzie zarządzania i ukierunkowywania firmy, wytyczania celów i inspirowania do nowych działań. Tworzy tym samym świetna platformę komunikowania się. Dzięki zrozumieniu misji firmy przez pracowników, oni sami lepiej rozumieją jak powinni postępować i jakie cele wytyczać.

- Ludzie w firmie są bardziej świadomi i odpowiedzialni. Wiedzą, jakie pozytywne wartości realizują, dopasowują do tego swoje codzienne działania, dlatego mocno ograniczone zostaje „ręczne sterowanie" czyli wydawanie poleceń wykonawczych. .

- Powoduje silniejsze utożsamianie się pracowników z firmą oraz buduje poczucie wspólnoty. To z kolei zwiększa motywację i zaangażowanie pracowników. Sprawia, że czują się oni bardziej odpowiedzialni za losy firmy, bardziej przykładają się do pracy oraz są skłonni do większych poświęceń.

- Przyczynia się do wzrostu sprzedaży oraz lepszego marketingu. Misja stanowi narzędzie komunikacji na zewnątrz, do klientów. Może służyć do poinformowania, jaką wartość firma chce im przekazać oraz w czym jest lepsza od konkurentów.

- Ułatwia zweryfikowanie i projektowanie ról i zadań w firmie (zarówno całych działów, jak i pojedynczych pracowników) pod kątem ich przydatności. Kiedy misja jest znana i czytelna, łatwiej jest dokonywać wyborów działań, które tworzą spójną całość i prowadzą do wspólnego celu

Misja przedsiębiorstwa ma strategiczne znaczenie, gdy spełnia tylko trzy wymogi (OBŁóJ K. 1998):

- wyznacza kierunek i dotyczy przyszłości,

- wyraża marzenia i wyzwania, które stają się udziałem pracowników,

- proces jej realizacji jest wiarygodny.

Należy pamiętać, że określenie misji jest początkiem określenia strategii przedsiębiorstwa. Proces ten został przedstawiony na rysunku 1. 


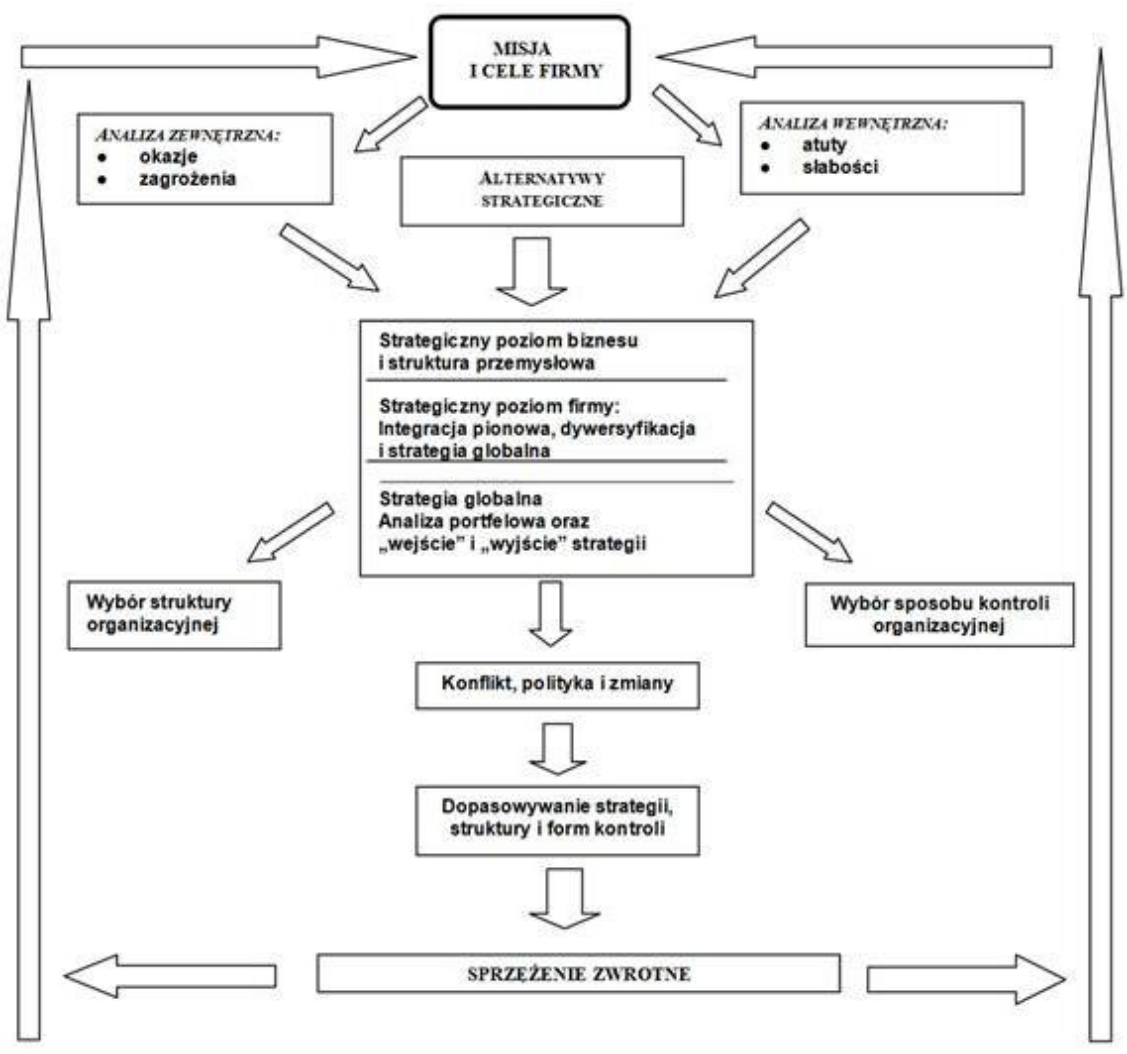

Rys. 1. Komponenty zarzadzania strategicznego.

Źródto: PENC J. 1994

King i Cleland wyodrębnili siedem niezbędnych celów, dla realizacji których warunkiem koniecznym jest sprecyzowanie misji podmiotu (CLELAND D.I., KING W.R. 1997):

1. Osiągnięcie jednoznaczności dążeń i zadań.

2. Dostarczenie podstawy dla alokacji zasobów.

3. Stworzenie podstaw i zasad dla właściwego użytkowania zasobów.

4. Określenie zasad tworzenia klimatu wewnątrz organizacji.

5. Dostarczenie pracownikom sposobu artykulacji oczekiwań. 
6. Ułatwienie tłumaczenia celów w operacyjną strukturę działania, która odzwierciedla priorytety.

7. Zasygnalizowanie odrębności.

\section{Funkcje i formy misji}

Dobrze opracowana misja przedsiębiorstwa ma określone funkcje do spełnienia. Najpełniejszy podział funkcji misji przedstawił Dwojnicki (DWOJNICKI P. 1995). Jego podział przedstawiono na rysunku 2.

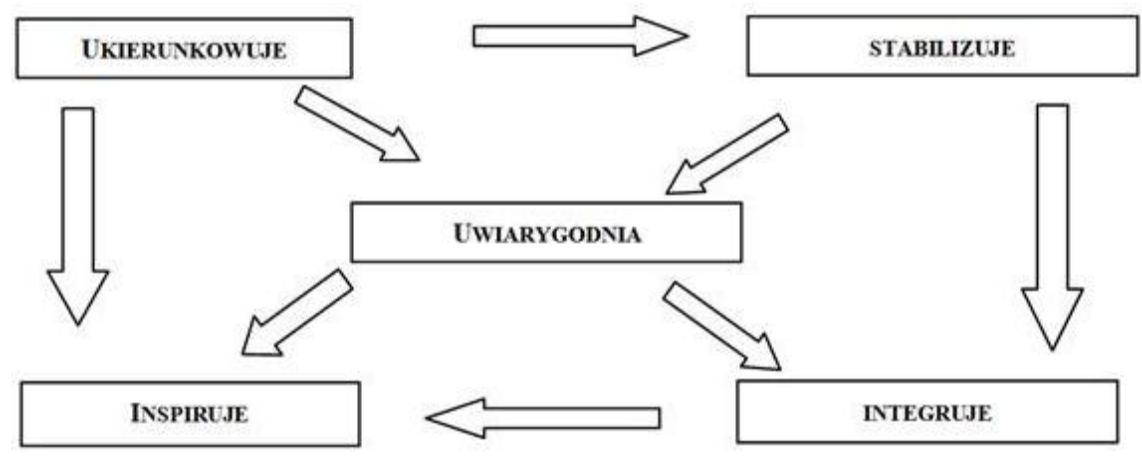

Rys. 2. Funkcje misji.

Źródto: DWOJNICKI P. 1995

Pierwsza funkcja misji jest funkcja ukierunkowująca. Oznacza ona, że prawidłowo skonstruowana misja umożliwia później precyzyjniejsze formułowanie poszczególnych celów strategicznych, pozwala uprościć procesy decyzyjne dotyczące wyborów optymalnych rodzajów działalności, oraz pomaga w skoncentrowaniu uwagi na tych aspektach i przejawach działalności podmiotu, które maja dla niego stanowić priorytet.

Funkcja stabilizująca oznacza, że misja przedsiębiorstwa stanowi czynnik określający pewien poziom pewności pracowników przedsiębiorstwa, co do trwałych zasad funkcjonowania całej organizacji. 
Praktycznie oznacza to, że nawet kiedy stawia się wysokie wymagania dotyczące ogólnej mobilności i nierzadko bardzo dynamicznych zmian charakteru pracy, ostatecznie kierownictwo podmiotu ciągle deklaruje $\mathrm{w}$ stosunku do swych pracowników stabilność wyznawanych tych samych wartości i kryteriów stanowiących priorytet działalności firmy.

Funkcja uwiarygodniająca misji realizowana jest $\mathrm{w}$ ten sposób, że czynne rozpropagowywanie treści samej misji i równoczesne potwierdzanie jej wiarygodności konsekwentną realizacją wyznaczonych zadań i dążeniem do osiągnięcia sformułowanych celów, prowadzić może w długim horyzoncie czasowym do ukształtowania się takiej tożsamości podmiotu oraz jego rynkowego wizerunku, który może stać się atutem poprzez pozytywne ustosunkowanie się do tej firmy podmiotów będących w jej bliższym lub dalszym otoczeniu

Funkcja integrująca misji koncentruje się na tym, że formułujące ją przedsiębiorstwo powinno poprzez swoją działalność spełniać rolę swego rodzaju czynnika, który skupia poszczególne grupy pracownicze wokół realizowania sformułowanej $\mathrm{w}$ misji strategii funkcjonowania firmy. Wiarygodnie opracowana misja podmiotu powinna powodować u personelu pracowniczego we nim zatrudnionego przekonanie, że ich indywidualna praca stanowi konieczny i niezbędny wkład do całości działalności prowadzonej przez to przedsiębiorstwo.

W myśl tych zaleceń formułowana misja w swoich założeniach powinna adaptować te elementy, które odwołują się do takich przekonań i wartości, które mogą być uznane za potencjalne źródło zbiorowej identyfikacji zatrudnionych $\mathrm{w}$ danym podmiocie pracowników $\mathrm{z}$ tym właśnie przedsiębiorstwem.

Funkcja inspirująca misji oznacza, że należy oczekiwać od niej otwarcia na ciągłe poszukiwania innowacji i wszelkich nowinek. Misja powinna więc inspirować do stałego doskonalenia firmy we wszystkich ważnych obszarach jej działania. Oznacza to, że znajomość misji ułatwiać powinna identyfikację niezbędnych zmian i sprzyjać ich realizacji. 
W literaturze można znaleźć również różne formy misji przedsiębiorstwa.

Misja podtrzymująca, zwana również stabilizującą, opierająca się na tożsamości podmiotu, której zasadniczy profil działalności został ukształtowany poprzez historyczny proces rozwoju danego przedsiębiorstwa i utrwalony w oparciu o jego dotychczasowe sukcesy. Formułowanie misji tego typu jest charakterystyczne przede wszystkim dla przedsiębiorstw dużych, o wieloletnich tradycjach i znaczących osiągnięciach.

Misja typu wizja rozwojowa jest zbudowana $\mathrm{z}$ komponentów określających tożsamość, jak i wizję przyszłości firmy. Skupia się na podtrzymywaniu istotnych rynkowo atutów przedsiębiorstwa i jednocześnie zapowiadaniu wprowadzenia nowoczesnych zmian optymalizujących dotychczasowe obszary, bądź sposoby działania przedsiębiorstwa na rynku.

Misja typu wizja przełomu jest budowana jest wyłącznie na bazie przyszłościowej, nowatorskiej wizji rozwoju przedsiębiorstwa. Oznacza to często wyrzeczenie się istotnych elementów dotychczasowej strategii rynkowej firmy, przerwanie ciągłości i radykalne odcięcie się od preferowanej do tej pory orientacji rozwoju.

Misja typu "Zamierzenie strategiczne" koncentruje się na prezentacji jasnego i dokładnie skonkretyzowanego celu danego podmiotu rynkowego, który ma być wypełniony w z góry wyznaczonym czasie.

Misja typu "Wspólny wróg" koncentruje się na ukazaniu w misji podmiotu wspólnego wroga całej załogi firmy. Podejście to jest typowe dla przedsiębiorstw, które chcą stać się liderem w danej branży, zdobyć pozycję dominującą na danym rynku.

Misja typu "Modelowy wzorzec" jest stosowana dość rzadko, a wykorzystują ją przede wszystkim małe i średnie przedsiębiorstwa, które dostrzegające przed sobą wielką przyszłość.

Misja typu "Przemiana wewnętrzna" jest szczególnie przydatna w odniesieniu do doświadczonych przedsiębiorstw potrzebujących pilnie zastosowania zmian, by zachować swoją siłę konkurencyjną lub by 
skorygować niekorzystne tendencje przejawiające się w rozwoju STONER J.A.F., WANKEL C. 1992).

\section{Projektowanie misji}

Według Druckera (DRUCKER P.F. 2003) podczas formułowania misji przedsiębiorstwa należy wziąć pod uwagę trzy zasadnicze grupy zagadnień:

- Okazje, jakie stwarza nam otoczenie, a więc przede wszystkim ujawnienie się nowych, nieznanych wcześniej potrzeb konsumentów, których zaspokojenie pozwoliłoby nam odnieść sukces.

- Kompetencje podmiotu, czyli integralny sposób i skalę, w jakich przedsiębiorstwo może zaspokoić wspomniane powyżej potrzeby. Należy tutaj oprzeć się na analizie posiadanej przez dany podmiot sumy zasobów ludzkich(m. in. personel wykonawczy, menagerowie, pracownicy obsługi), technicznych (m. in. maszyny, urządzenia, budynki i budowle) i finansowych ( $\mathrm{m}$. in. zasoby pieniężne, papier wartościowe, udziały $\mathrm{w}$ innych podmiotach i jednostkach stowarzyszonych).

- Zaangażowanie, które wynika ze stopnia zgodności członków organizacji z potrzebami i wzorami kulturowymi, a istotą jej działalności.

Misja powinna być pisana językiem przystępnym i zrozumiałym dla każdego, zajmując tak mało miejsca, jak to tylko możliwe. Należy pamiętać, że misja ta skierowana jest do potencjalnych klientów. Nie muszą się oni posługiwać tych samym językiem, co przedsiębiorstwo. Przeciętny klient nie zna języka technicznego lub sie nim słabo posługuje. Dlatego prostota misji jest tak ważna.

Ważne jest, aby sformułowana misja mieściła się w jednym zdaniu. To również pozwoli na lepsze zrozumienie przez czytającego. Co więcej, zbyt długa misja może być dla niego po prostu nużąca, co oznacza, że może nie skończyć jej czytać. A zatem „technicznie”, sformułowanie misji to jedno zdanie z czasownikiem (czasownikami), określającym, co 
robi przedsiębiorstwo dla swoich potencjalnych klientów. Te czasowniki są ważne, ponieważ wskazują na konkretne działania na rzecz klientów (KISIL A., DUDZIAK W. 2012).

Dlatego ważne jest, aby pamiętać o kilku prostych zasadach w trakcie określania misji:

- zwięzłość - nie powinna przekraczać jednego zdania,

- zrozumiałość - używanie prostego języka, zrozumiałego zarówno dla klientów jak i pracowników,

- prawdziwość - misja powinna odzwierciedlać rzeczywiste działania przedsiębiorstwa, a nie obiecywać niemożliwego,

- formułowanie w sposób pozytywny - przedsiębiorstwo powinno wskazać, co robi, a nie czego unika,

- wskazywanie działania firmy - np. misja piekarni: "pieczemy zdrowy chleb" wskazuje na dwa ważne działania, że piekarnia ta piecze chleb oraz dba o zdrowie swoich klientów,

- oryginalność - nie wolno kopiować misji innych przedsiębiorstw,

- elastyczność - przedsiębiorstwo musi mieć możliwość zmiany misji.

\section{Realizacja misji}

Przez realizację misji rozumiany jest całokształt działań podmiotu, jakie muszą być wprowadzone w życie, aby obietnica złożona klientowi mogła zostać wypełniona. Aby zrealizować tę obietnicę i w rezultacie zapewnić sobie w miarę trwały sukces, przedsiębiorstwo musi umiejętnie wykorzystać wszystkie posiadane przez siebie zasoby. Jako najistotniejszy $\mathrm{z}$ nich, zapewniający niewątpliwie $\mathrm{w}$ pierwszym rzędzie sukces podmiotu, uważa się pracowników, wraz z ich wszechstronnymi umiejętnościami, talentami i kompetencjami. Dopiero odpowiednie zagospodarowanie tego zasobów ludzkich może zapewnić właściwe wykorzystanie wszystkich pozostałych zasobów i w konsekwencji właściwie ukształtować plan dalszego działania przedsiębiorstwa. Ten $\mathrm{z}$ kolei powinien być sformułowany $\mathrm{w}$ taki sposób, aby zapewniał 
osiągnięcie przyjętych przez dany podmiot celów (STOCHOWSKI W. 1994). Proces realizacji misji został przedstawiony na rysunku 3.

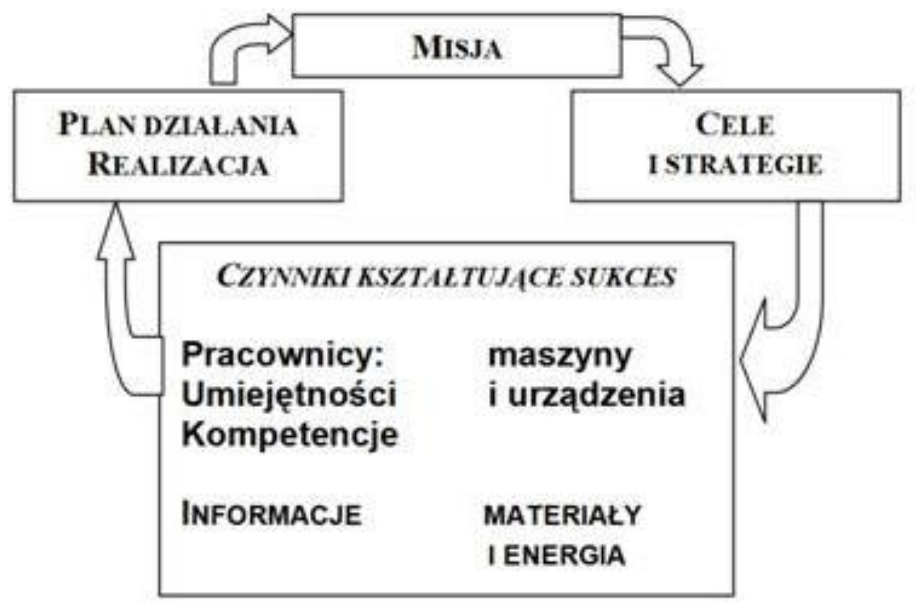

Rys. 3. Cykl realizacji misji przedsiębiorstwa.

Źródto: STосношSкI W. 1994

\section{Przykłady misji przedsiębiorstw różnych branż}

W Polsce i na świecie istnieje wiele branż, w którym może działać przedsiębiorstwo. Jednak pomimo różnicy branż każde przedsiębiorstwo określa swoją misję.

Dla przykładu przedstawionych zostanie kilka misji $\mathrm{z}$ uwzględnieniem różnych branż, w których działają przedsiębiorstwa.

Jak przykład administracji przedstawiono misję Powiatowego Urzędu Pracy w Mysłowicach (www.myslowice.pup.gov.pl). Misja PUP brzmi:

„Misją wszystkich pracowników urzędu pracy jest stałe dążenie do poprawy sytuacji na lokalnym rynku pracy, troszczenie się o taki rozwój postaw, umiejętności i kwalifikacji mieszkańców, który zapewni im możliwie największe szanse na odpowiednie zatrudnienie, a pracodawcom pozyskanie najlepszych pracowników. Swoją misję urząd 
pracy realizuje poprzez świadczenie wysokiej jakości usług informacyjnych, pośrednictwa pracy, doradczych, szkoleniowych, finansowych i administracyjnych. Zadania realizuje zgodnie z europejskimi i krajowymi standardami świadczenia usług”.

Kolejnym przykładem jest bank PKO BP (www.pkobp.pl/). Jego misja brzmi:

„Zgodnie z realizowaną aktualnie strategią na lata 2010 - 2012 Bank zamierza utrzymać uniwersalny, polski charakter. Chce wzmocnić pozycję lidera we wszystkich ważnych segmentach rynku. Będzie kontynuował zrównoważony rozwój, skupiony na rozpoznaniu i zaspokajaniu potrzeb klientów, z którymi chce budować silne długookresowe relacje. Dzięki zwiększonej sprawności operacyjnej zdecydowanie poprawi jakość obsługi swoich klientów. Równocześnie będzie dbać o zachowanie stabilnej rentowności zgodnej z oczekiwaniami akcjonariuszy, prowadzącym ostrożną politykę zarządzania ryzykiem. PKO Bank Polski chce być postrzegany jako bezpieczny, ale i jednocześnie nowoczesny bank $\mathrm{z}$ tradycjami. Aby przyciągnąć najbardziej wartościowych pracowników ma ambicje stać się najlepszym pracodawcą w polskim sektorze finansowym."

Przykładem przedsiębiorstwa produkcyjnego jest Huta CMC Zawiercie S.A. (stage.cmc.com/cmcpoland/Misja.aspx). Jej misja brzmi:

„My, CMC Zawiercie S.A., uważamy za naszą misję umacnianie pozycji naszej firmy w Polsce i w krajach sąsiadujących, jako najbardziej wydajnego producenta wysokiej jakości długich wyrobów stalowych oraz firmy oferującej pionowo zintegrowany system świadczenia usług."

Jako przykład szkoły autorzy wybrali uczelnię, w której pracują Politechnikę Częstochowską (www.pcz.pl). Jej misja brzmi:

„Misja Politechniki Częstochowskiej to rozwijanie i upowszechnianie postępu technicznego oraz świadomości ekonomicznej, a także współdziałanie w szerzeniu wiedzy w społeczeństwie, dbanie o zdrowie i rozwój fizyczny przyszłej kadry specjalistów, zgodnie z ideałami humanizmu i demokracji." 
Przykładem sklepu może być ogólnopolska sieć Leroy Merlin (www.leroymerlin.com/pl/misja-1). Jej misja przedstawiona jest $\mathrm{w}$ formie bardzo krótkiej:

„Sieć Leroy Merlin pomaga swoim klientom w projekcie i realizacji wymarzonego mieszkania. Kierownik produktu, księgowy, logistyk, doradca sprzedaży w sklepie..., wszyscy pracownicy mają swój udział w tej podstawowej misji."

Jako przykład szpitalu przedstawiono misję Szpitala Bielańskiego w Warszawie (www.bielanski.med.pl/misja.html):

„Misją Szpitala Bielańskiego jest udzielanie świadczeń zdrowotnych na możliwie najwyższym poziomie jakości w zakresie dostępnych środków finansowych, zgodnie $\mathrm{z}$ zasadami sztuki medycznej, doświadczeniem personelu, najlepszymi tradycjami, osiągnięciami naukowymi oraz nowymi technologiami medycznymi, w przyjaznych i bezpiecznych warunkach pobytu oraz pracy."

\section{Literatura}

1. WAWRZYNIAK W. 1989. Polityka strategiczna przedsiębiorstwa. PWN, Warszawa.

2. STONER J. A. F., WANKeL C. 1992. Kierowanie. PWE, Warszawa.

3. Stоchowsкi W. 1994. Jak definiować misję. Przegląd Organizacji, nr 11.

4. Sudoł S. 1999. Przedsiębiorstwo. Podstawy nauki o przedsiębiorstwie. Teorie i praktyka zarzadzania. Wyd. Dom Organizatora, Torun.

5. DWOJNICKI P. 1995. Składniki misji - wizja przysztości. Przegląd Organizacji, nr 12.

6. PIERŚCIONEK Z. 1996. Strategie rozwoju firmy. PWE, Warszawa.

7. KISIL A., DUDZIAK W. 2012. ABC zarzadzania strategicznego: czym jest misja firmy?. Zarządzanie strategiczne 27.08.2012.

8. http://www.investopedia.com (10.08.12)

9. KoźMIŃSKI A. K. 1998. Zarzadzanie. Teoria i praktyka. Wydawnictwo Naukowe PWN, Warszawa. 
10. RADTKE J. M. 1998. How to write a mission statement. The Grantsmanship Center http://www.tgci.com/magazine/How\%20to\%20Write\%20a\%20Missi on\%20Statement.pdf (10.08.12).

11. Hill CH., JONES G. 2008. Strategic Management. Houghton Mifflin Company, New York.

12. OвŁóJ. K. 1998. Strategia sukcesu firmy. PWE, Warszawa.

13. PENC J. 1994. Strategie zarządzania. Ag. Wyd. Placet.

14. Cleland D.I., KING W.R. 1997. Project Management Handbook. Wyd. John Wiley \& Sons, New York, USA.

15. DRUCKER P.F. 2003. Praktyka zarzadzania. Wydawnictwo MT Biznes.

16. www.myslowice.pup.gov.pl (10.08.12).

17. www.pkobp.pl (10.08.12).

18. stage.cmc.com/cmcpoland/Misja.aspx (10.08.12).

19. www.pcz.pl (10.08.12).

20. www.leroymerlin.com/pl/misja-1 (10.08.12).

21. www.bielanski.med.pl/misja.html (10.08.12). 